\title{
ОСОБЛИВОСТІ РОСТУ І РОЗВИТКУ ТА ВПЛИВ АБСОРБЕНТІВ НА ВРОЖАЙНІСТЬ І ЯКІСТЬ ОВОЧЕВИХ РОСЛИН
}

\author{
Улянич О. І., Шевчук К. М.
}

\section{ВСТУП}

Високу врожайність овочевих рослин у посушливих умовах можна отримати, забезпечивши їх оптимальними умовами росту. У науковій літературі рекомендується для сприяння росту застосовувати абсорбенти ${ }^{1,2}$.

Абсорбенти - природні або синтетичні сполуки, які використовуються для внесення у грунт із метою ініціювання змін у процесах їх життєдіяльності для покращення якості продукції, збільшення врожайності, полегшення збирання і зберігання врожаю. Використання абсорбентів веде до змін в обміні речовин, аналогічних тим, що виникають під впливом зовнішніх умов. Тобто абсорбенти - це не поживні речовини, а фактори забезпечення росту і розвитку рослин ${ }^{3,4}$.

Абсорбенти активізують у рослинах основні життєві процеси. Під їх дією прискорюється наростання зеленої маси та кореневої системи, активно використовуються вода і розчинені в ній поживні речовини грунту та мінеральних добрив, їх стійкість до захворювань, зміни температур, посухи, відповідно, підвищується урожайність та поліпшується якість овочів ${ }^{5}$.

Застосування абсорбентів дає змогу повніше реалізувати потенційні можливості рослин, закладені природою та селекцією ${ }^{6}$.

Основна вимога до абсорбентів - висока вбирна здатність щодо компонента, який абсорбується. Цінною якістю абсорбентів $\epsilon$ можливість їх регенерації. Крім того, абсорбент має бути хімічно індиферентним та стабільним (не розщеплюватися, не окислюватися, не осмолюватися тощо), дешевим та корозійно неактивним ${ }^{7}$.

\footnotetext{
Курченко А.А., Коваль В.В. Урожайність сортів шпинату городнього залежно від водоутримуючих речовин. Технологічні аспекти вирощування часнику, інших циибулевих і с.-г. рослин : Всеукраїнська науково-практична конференція, 21-22.09.2017. Умань. 2017. С. 40-45.

2 Ульянич Е.И., Алексейчук O.М., Прудкий Р.И., Диденко И.А. Применение биопрепаратов для получения экологически безопасной продукции шпината огородного и сельдерея черешкового. Научные статьи Государственного аграрного университета Молдовы. 2015. Вып. 42. С. $225-227$.

${ }^{3}$ Гідрогель AQUASORB. URL: http://www.gidrogel.org.

${ }^{4}$ Гидрогель в растениеводстве. URL: http://www.avroragro.ru.

${ }^{5}$ AGPRO NZ Limited WATER RETENTION CRYSTALS WaterAbsorbentPolymer. URL: http://www.agpro.co.nz/label/AGPRO\%20Water\%20Retention\%20Crystals. pdf

6 Паламарчук I.I. Ефективність застосування водоутримуючих гранул Аквод при вирощуванні кабачка за мульчування грунту в Правобережному Лісостепу України. Збірник наукових праць НУБІП. 2014. Вип. 40. С. 74-81.

${ }^{7}$ Ульянич Е.И., Диденко И.А., Яценко В.В. Выращивание сельдерея черешкового при помощи различных форм гидрогеля в условиях Правобережной Лесостепи Украины. Инновачионные подходbl 666
} 
Залежно від характеру сорбції розрізняють абсорбенти, які утворюють із поглинутою речовиною твердий або рідкий розчин ${ }^{8}$.

У засушливих умовах сучасного клімату абсорбенти сприяють підвищенню врожайності овочів та отриманню високої якості продукції. Питанням застосування абсорбентів у технології вирощування овочів присвячено незначну кількість досліджень, але рослини страждають від сучасних змін клімату та посушливих умов вирощування навіть у Лісостепу України, ${ }^{9}$.

За останні роки питанням вивчення нових елементів у технології вирощування овочів присвячено роботи багатьох вчених-овочівників і практиків ${ }^{11,12,13,14,15 .}$

Тому актуальність теми зумовлює проведення та обгрунтування напрямів наукового пошуку.

Мета досліджень - вивчити вплив застосування різних форм абсорбентів на зростання, розвиток, якісні показники та загальну урожайність шпинату городнього, селери черешкової i часнику посівного.

Експериментальну частину дослідження 3 вивчення впливу застосування абсорбентів на ріст, врожайність і якість овочевих рослин шпинату городнього, селери черешкової і часнику посівного виконано на кафедрі овочівництва та науковій лабораторії масових аналізів Уманського національного університету садівництва. Метеорологічні

и перспективные идеи молодых ученых в аграрной науке : Сборник материалов Международной научно-практической конференции молодих учених, 17 ноября 2017 г., п. Кайнар. Innovative approaches and perspective ideas of young scientists in agrarian sciences: The proceed. of intern. sc. pract. conf. young scient. (November 17, 2017, KainarTown). Алматы: Таугуль-Принт, 2017. С. 552-555.

${ }^{8}$ Aworh O.C., Hicks I.R., Minotti P.L., Loe C.G. Effect of plant ageand nitrogen fertilisation nitrite accumulation in frech Spinach. J. Amer. Soc. HortSci. 1980. 105. № 1. P. 18-20.

9 Ульянич Е.И., Алексейчук О.М., Прудкий Р.И., Диденко И.А. Применение биопрепаратов для получения экологически безопасной продукции шпината огородного и сельдерея черешкового. Научные статьи Государственного аграрного университета Молдовы. 2015. Вып. 42. С. $225-227$.

${ }^{10}$ Воробйова Н.В., Кухнюк О.В., Прудкий Р.І. Нанотехнології в овочівництві України. VI (21), Issue 179, 2018. Sept. SCIENCE AND EDUCATION A NEW DIMENSION https://doi.org/10.31174/ SEND-NT2018-179VI21Natural and Technical Sciences. C. 13-15. https://doi.org/10.31174/SENDNT2018-179VI21-03.

11 Улянич O.I., Вдовенко С.А., Ковтунюк 3.І., Кецкало В.В. та ін. Біологічні особливості і вирощування малопоширених овочів. Умань : Візаві, 2018. 280 с.

12 Osokina N., Kostetska K., Kuhnyuk O., Shevchuk K. Quality management of vegetables with the application of nano preparations. Збірник наукових праџь Уманського наџіонального університету садівниитва. Ч. І. Сільськогосподарські науки. 2020. Вип. 96. С. 179-193. DOI 10.31395/2415-82402020-96-1-178-193.

${ }^{13}$ Ulianych O., Kostetska K., Vorobiova N., Shchetyna S., Slobodyanyk G. and Shevchuk K. Growth and yield of spinach depending on absorbents' action. Agronomy Research 18(X), xxx-ccc, 2020. https://doi.org/10.15159/AR.20.012.

${ }^{14}$ Polischuk V.V., Polischuk T.V., Kezkalo V.V., Vorobiova N.V. Effekt of application of modified nourishing environment on the reproduction and yielding capacity of root celery. Ukrainian Journal of Ecology, 2018. 8(2). 113-119. DOI: 10.15421/2018_317.

${ }^{15}$ Ulianych O.I., Schetyna S.V., Slobodianyk G.Ya., Ternavskyi A.G., Kuhniuk O.V., Didenko I.A. Ecological Status of Soils and Vegetable Products in Cherkasy Region. Ukrainian Journal of Ecology. 2018. 8(3). 10-19. DOI: 10.15421/2018_317. 
фактори регіону досить нестійкі, що підтверджено багаторічними даними метеостанції «Умань». Встановлення ефективності застосування абсорбентів для овочевих рослин та вплив на ріст, розвиток i урожайність проводили із сортами шпинату городнього Красень Полісся і Малахіт, часнику посівного - Мануйлівський, селери черешкової Монарх, Аніта, Діамант. Досліджували абсорбенти у формі таблетки, гелю і гранул фірми Максимарин. Як контроль використовували варіант без внесення абсорбенту. Дослід закладався в чотириразовому повторенні. Площа загальної ділянки $5 \mathrm{~m}^{2}$, облікової $-3 \mathrm{~m}^{2}$. Насіння шпинату висівали і розсаду селери розміщували за схемою $45 \times 15 \mathrm{~cm}$, часнику посівного $-45 \times 6$ см. Програмою дослідження передбачалося проведення фенологічних спостережень, біометричних вимірювань, облік врожайності та якості продукції за загальноприйнятими методиками. Дослідження проведено канд. с.-г. наук I.А. Діденком ${ }^{16}$, P.I. Прудким ${ }^{17}$, К.М. Шевчуком під керівництвом доктора с.-г. наук, професора О.І. Улянич.

\section{1. Фенологічні і біометричні спостереження}

за овочевими рослинами залежно від форми абсорбенту

Проведені фенологічні спостереження за овочевими рослинами залежно від дії абсорбенту свідчать, що грунтово-кліматичні умови Правобережного Лісостепу України відповідають біологічним особливостям досліджуваних рослин. Встановлено, що чим коротший період від сівби до з'явлення сходів, тим швидше рослина вступає в пору плодоношення.

Наведені дані свідчать, що вплив біологічних особливостей сортів шпинату городнього і внесених абсорбентів виявлявся по-різному. Сходи масові з'являлися в сорту Красень Полісся в контролі за 9 діб, а за внесення абсорбенту спостерігали більш швидке з'явлення сходів через 6-8 діб.

Наростання зеленої маси рослин відбувалося досить швидкими темпами, про що свідчать міжфазні періоди. Так, перші листки у шпинату з'явилися найраніше за внесення абсорбенту у формі гелю. Фаза початку утворення розетки наставала, коли в рослин шпинату виростали чотири листки, і це відбувалося найраніше в сорту Малахіт за внесення гелю і абсорбенту з калієм. Більший вегетаційний період помічено в рослин, які росли без внесення абсорбенту - 45-46 діб. Сорт Малахіт за внесення гелю і гранул мав на 7 діб менший вегетаційний

\footnotetext{
16 Діденко І.А. Оптимізація технології вирощування селери черешкової у Правобережному Лісостепу України : автореф. дис. ... канд. с.-г. наук : 06.01.06 «Овочівництво». Умань, 2018. 24 с.

17 Прудкий P.I. Технологічні особливості формування урожайності шпинату городнього за органічного виробництва у Правобережному Лісостепу України : автореф. дис. ... канд. с.-г. наук : 06.01.06 «Овочівництво». Умань, 2019. 25 с.
}

668 
період. Абсорбенти сприяли швидшому проростанню селери черешкової та часнику раніше на 4-6 діб і надходженню продукції на 7-9 діб.

Біометричні спостереження за рослинами залежно від форми абсорбенту показали, що відбувається істотний вплив на прискорення росту і розвитку рослин та отримання вищої врожайності. Важливе значення для рослин мають площа листка та їх кількість. У шпинату городнього кількість листків коливається в межах 17-23 шт./росл. (рис. 1).

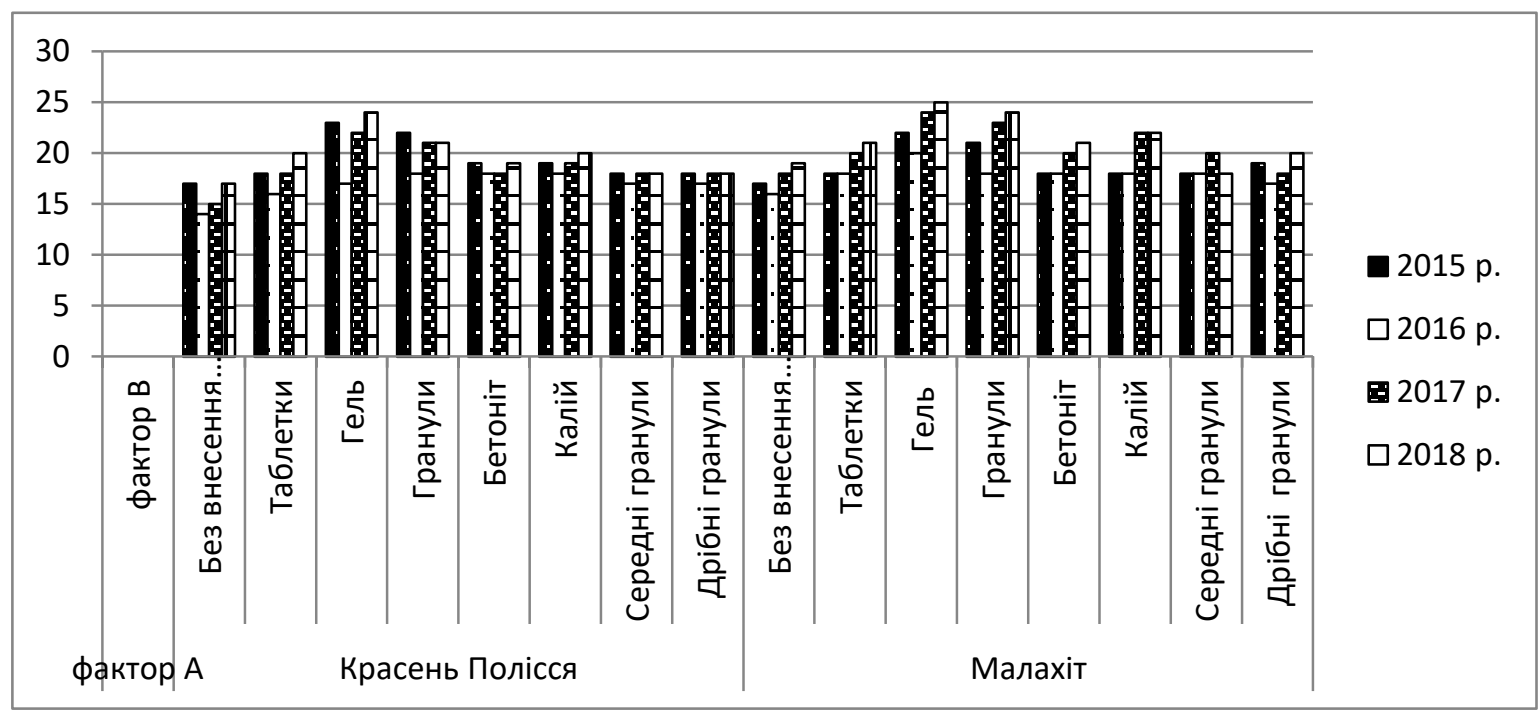

Рис. 1. Кількість листків у шпинату городнього у фазу технічної стиглості зелені залежно від дії форми абсорбенту, шт./росл.

Дані отримано Р.І. Прудким, О.І. Улянич

Вирощування шпинату на фоні застосування різних форм абсорбенту сприяло збільшенню кількості листків за внесення таблеток у сорту Красень Полісся до 18 шт./росл., у сорту Малахіт - до 19 шт./росл., що було вищим за контроль на 2-3 шт./росл. Внесення абсорбенту у вигляді гелю в сорту Красень Полісся сприяло збільшенню кількості листків до 22 шт./росл., у сорту Малахіт - до 23 шт./росл., що переважало контроль на 6-7 шт./росл. Внесення гранул викликало дещо нижчий ефект, але перевага до контролю була досить високою і становила 5-6 шт./росл.

У роки дослідження погодні умови впливали по-різному на величину листкової поверхні шпинату городнього. Без внесення препарату площа листка становила в сорту Красень Полісся $105,6 \mathrm{~cm}^{2}$, у сорту Малахіт $106 \mathrm{~cm}^{2}$. Вирощування шпинату на фоні застосування різних форм абсорбентів сприяло збільшенню площі листка і за внесення таблеток у сорту Красень Полісся становила $108,9 \mathrm{~cm}^{2}$, у сорту Малахіт $-104,8 \mathrm{~cm}^{2}$, що було вищим за контроль на $0,8-3,3 \mathrm{~cm}^{2}$. Внесення абсорбенту у 
вигляді гелю у сорту Красень Полісся сприяло збільшенню площі одного листка до $113,1 \mathrm{~cm}^{2}$, у сорту Малахіт - до $112,5 \mathrm{~cm}^{2}$, що також переважало контроль на 6,9-7,3 см². Внесення гранул викликало дещо нижчий ефект, але перевага до контролю була досить високою i становила 3,3-6,9 $\mathrm{cm}^{2}$ (табл. 1).

Таблиця 1

Площа листків шпинату городнього залежно від дії абсорбентів (середне за 2015-2018 рр.)**

\begin{tabular}{|c|c|c|c|}
\hline Сорт & Препарат & $\begin{array}{c}\text { Площа } \\
\text { листка, } \text { см}^{2}\end{array}$ & $\begin{array}{c}\text { Загальна площа } \\
\text { листків, тис. } \text { мга }^{2}\end{array}$ \\
\hline \multirow{8}{*}{$\begin{array}{l}\text { Красень } \\
\text { Полісся }\end{array}$} & $\begin{array}{l}\text { Без внесення } \\
\text { абсорбенту* }\end{array}$ & 105,6 & 24,6 \\
\hline & Таблетки & 108,9 & 29,1 \\
\hline & Гель & 113,1 & 36,1 \\
\hline & Гранули & 112,5 & 34,2 \\
\hline & Бетоніт & 110,2 & 30,3 \\
\hline & Калій & 112,4 & 31,7 \\
\hline & Середні гранули & 110,8 & 29,2 \\
\hline & Дрібні гранули & 111,8 & 29,4 \\
\hline \multirow{8}{*}{ Малахіт } & $\begin{array}{l}\text { Без внесення } \\
\text { абсорбенту }\end{array}$ & 106,0 & 27,5 \\
\hline & Таблетки & 104,8 & 29,9 \\
\hline & Гель & 112,5 & 38,1 \\
\hline & Гранули & 108,9 & 34,9 \\
\hline & Бетоніт & 104,8 & 30,0 \\
\hline & Калій & 109,4 & 32,5 \\
\hline & Середні гранули & 108,5 & 29,8 \\
\hline & Дрібні гранули & 105,6 & 29,0 \\
\hline
\end{tabular}

*-контроль, **-дані отримано Р.І. Прудким, О.І. Улянич

Важливим показником росту рослин шпинату городнього, який визначав його цінність як зеленої рослини, була загальна площа листків і у сорту Малахіт у фазу технічної стиглості рослини без внесення абсорбенту досягла рівня 24,6 тис. м²/га. Вищими показниками вирізнялися варіанти, де вносили гель і гранули, - 34,2-38,1 тис. м $^{2} /$ га, що переважало контроль на 9,6-13,5 тис. $\mathrm{m}^{2} /$ га. Внесення гранул із калієм та середніх гранул фірми Еко давало позитивний результат, i площа листків відповідала показнику 29,2-32,5 тис. м²/га, що було більше до контролю на 4,6-7,9 тис. $\mathrm{m}^{2} /$ га.

Визначення площі листка в селери черешкової показало, що в сорту Монарх більшими були листки за застосування таблеток - 66,6 cм². 
Меншими за цим показником були листки за застосування гранул $61,1 \mathrm{~cm}^{2}$. У сорту Аніта рослини мали дещо нижчу площу листка, ніж у сорту Монарх. Обчислення загальної площі листків селери черешкової залежно від сорту та форми абсорбенту перед збиранням врожаю показало, що більшим цей показник був у сорту Монарх за внесення таблеток $-16,9$ тис. $\mathrm{m}^{2} /$ га проти контролю - 15,1 тис. $\mathrm{m}^{2} /$ га.

Значення показника листкового індексу вказує на недостатне перекриття площі грунту рослинами селери. У досліджуваних сортів за всіх варіантів досліду цей показник був на рівні 1,3-1,7.

У часнику листок $\epsilon$ показником росту і має визначальне значення для оцінки його якостей. Так, у 2020 р. кількість листків знаходиться у межах 7-13 шт./росл. Більшою кількістю листків вирізнялися рослини, що росли за внесення абсорбентів у формі гелю і гранул 12-13 шт./росл. У 2019 р. кількість листків була нижчою внаслідок гірших умов вирощування і знаходилася в межах 10-11 шт./росл. Більшу кількість листків отримано за внесення гелю і гранул - 12-15 шт./росл., що істотно перевищувало контроль на 6-9 шт./росл. Вирощування часнику на фоні застосування різних форм абсорбентів сприяло збільшенню площі листка i за внесення таблеток вона становила $18,9 \mathrm{~cm}^{2}$. Внесення гелю сприяло збільшенню площі листка до $19,1 \mathrm{~cm}^{2}$, що переважало контроль на 6,9-7,3 cм². Внесення гранул викликало дещо нижчий ефект, але перевага до контролю була досить високою і становила 3,3-6,9 $\mathrm{cm}^{2}$.

Загальна площа листків часнику посівного у фазу технічної стиглості без внесення абсорбенту досягла рівня 14,0 тис. м²/га. Вищими показниками вирізнялися варіанти, де вносили гель i гранули, -

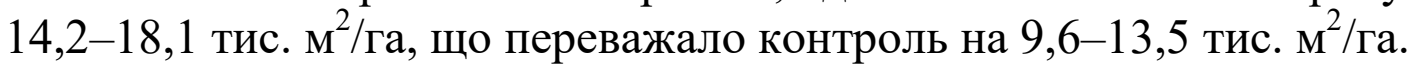

Довжина черешка селери залежно від сорту та застосування різних форм абсорбенту коливалась від 27,9 до 34,8 см. Нижчою спостерігалася за застосування таблеток, а вищою - за застосування гранул (30,2-34,4 см) та гелю (34,6-34,8 см) (рис. 2).

Помічено, що діаметр черешка мав розбіжності в межах сорту та форми абсорбенту. У сорту Монарх діаметр черешка в контролі та за застосування таблеток становив 14,0 мм. За внесення гранул та гелю він істотно збільшувався - 15,2 та 15,8 мм відповідно. У сорту Аніта діаметр черешка був більшим за внесення гелю - 16,2 мм, за внесення гранул та 16,0 мм (+2,2 та +2,0 мм до контролю) (рис. 3).

Помічено, що в сорту Діамант діаметр черешка був на рівні від 14,8 мм за застосування гелю до 15,6 мм за застосування гранул. Кращі показники отримали в сорту Аніта за застосування гелю - 16,2 мм (рис. 4). 


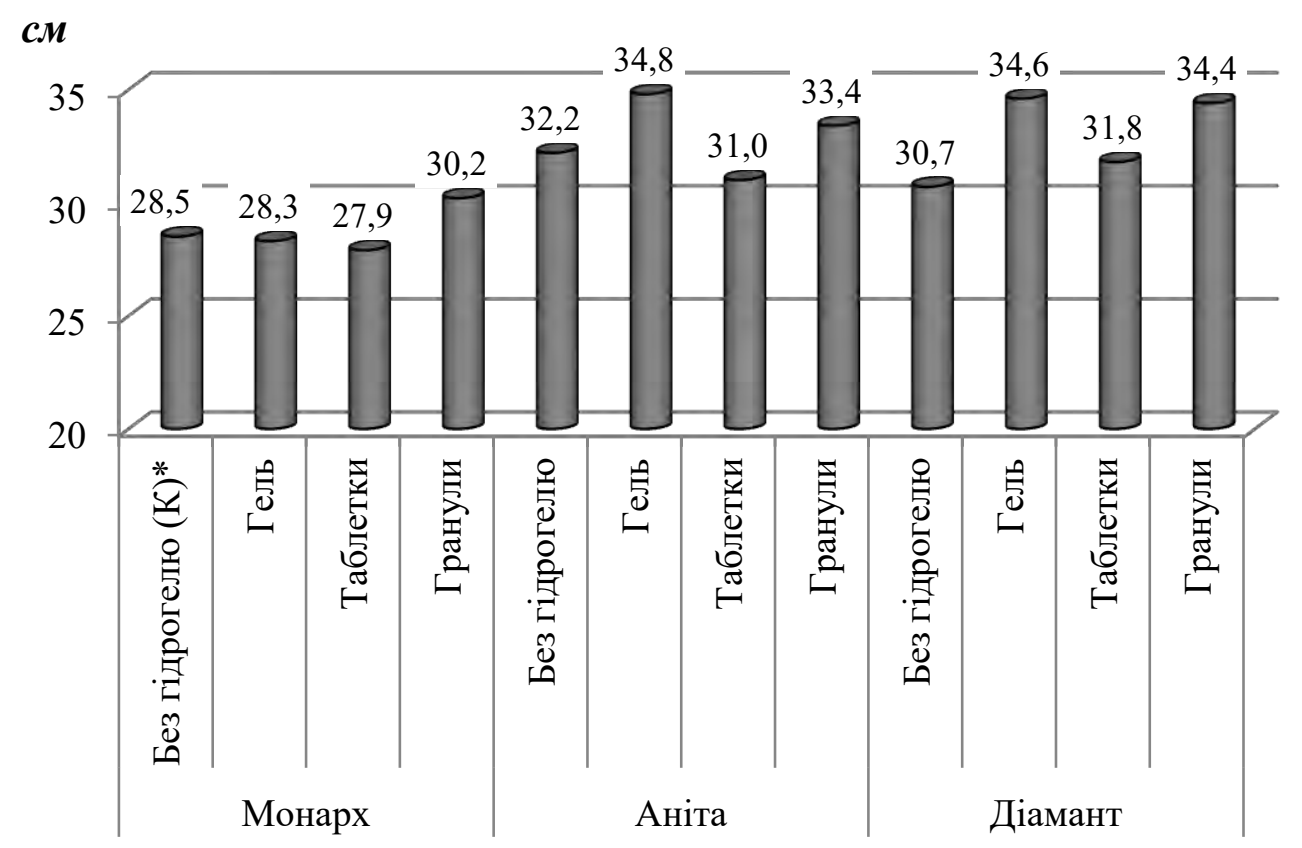

Рис. 2. Довжина черешка селери залежно від сорту та форми абсорбенту, см (середнс за 2015-2017 рр.)

Дані отримані І.А. Діденком, О.І. Улянич

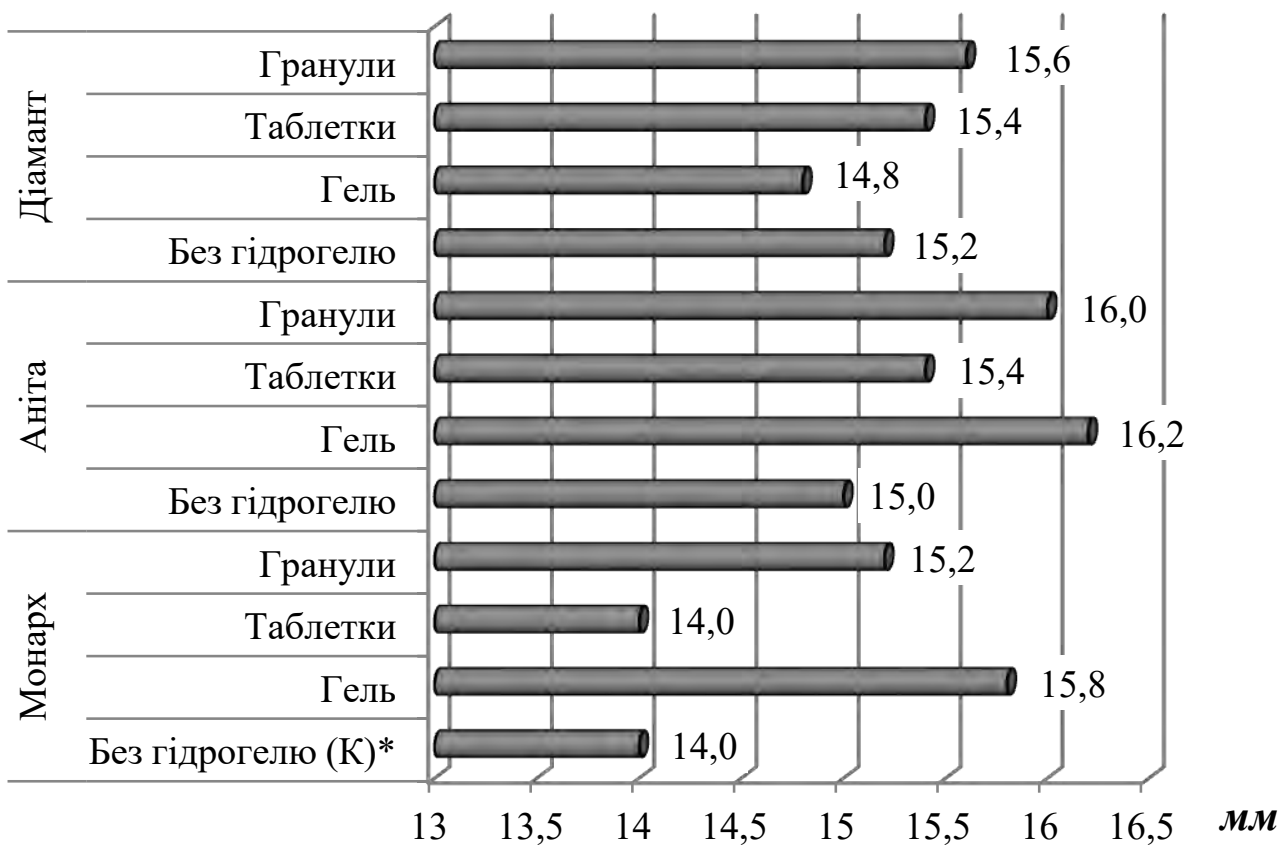

Рис. 3. Діаметр черешка селери залежно від сорту та форми абсорбенту, мм (середнє за 2015-2017 рр.)

Дані отримані І.А. Діденком, О.І. Улянич 
шт./росл.

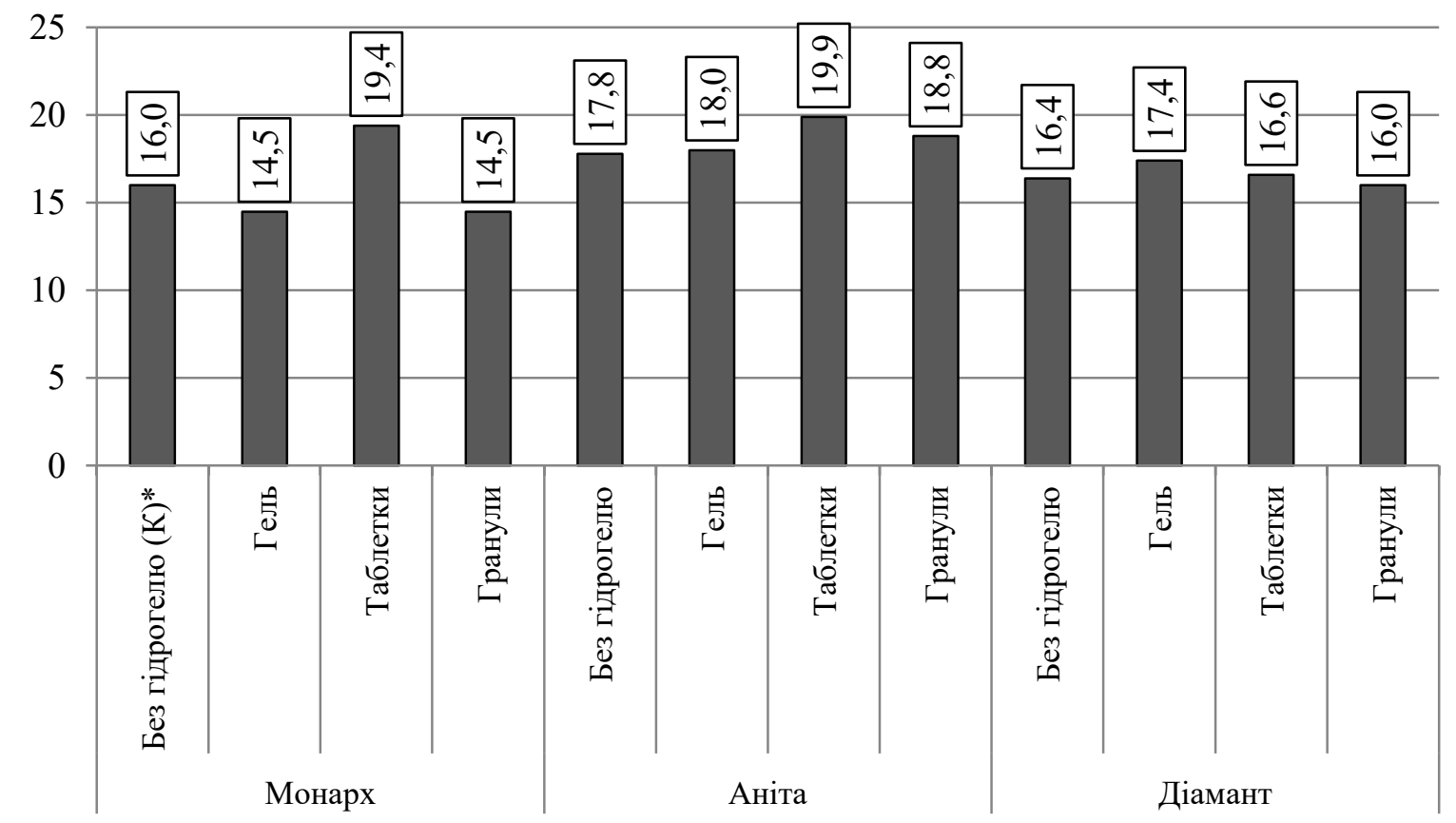

Рис. 4. Кількість черешків на рослині селери залежно від сорту та форми абсорбенту, шт./росл. (середне за 2015-2017 рр.)

Дані отримані І.А. Діденком, О.І. Улянич

\section{2. Урожайність овочевих рослин залежно від форми абсорбенту}

Поліпшення умов вирощування шпинату в результаті застосування різних форм абсорбенту, навіть за посухи, дало змогу отримувати більшу масу рослини (табл. 2).

Аналіз отриманих даних показав, що в період закінчення інтенсивного росту розетки i перед збиранням врожаю найменша маса шпинату городнього була в сорту Красень Полісся і Малахіт без внесення препарату, яка становила 108 г і 133 г. Більшу масу мали рослини шпинату сорту Малахіт за внесення гранул і гелю і гранул із калієм фірми Еко - 171-178 г, що істотно переважало контроль (на 63-70 г).

Маса надземної частини селери черешкової сорту Монарх була вищою за використання гелю - 341,5 г (+29,2 г до контролю). У сорту Аніта за використання гелю маса була вищою - 417,6 г та істотно перевищувала контроль на 105,3 г. У сорту Діамант вищі показники отримано теж за використання гелю - 381,7 г (рис. 5).

Маса рослини селери за застосування гелю знаходилася в межах від 245,4 г у сорту Монарх до 289,9 г у сорту Аніта. Істотно більшу масу рослини спостерігали за застосування гелю в сорту Аніта $266,8-277,5$ г, середню в сорту Діамант - 254,1-260,7 г, а меншу в сорту Монарх - 214,9-241,1 г. 
Таблиця 2

Маса рослини шпинату городнього

перед збиранням врожаю залежно від дії абсорбенту, г **

\begin{tabular}{|c|c|c|c|c|c|c|}
\hline $\begin{array}{c}\text { Cорт } \\
\text { фактор } \\
\mathbf{A} \\
\end{array}$ & $\begin{array}{l}\text { Препарат } \\
\text { фактор B }\end{array}$ & $\begin{array}{c}2015 \\
\text { p. }\end{array}$ & $\begin{array}{c}2016 \\
\text { p. }\end{array}$ & $\begin{array}{c}2017 \\
\text { p. }\end{array}$ & $\begin{array}{c}2018 \\
\text { p. }\end{array}$ & $\begin{array}{l}\text { Середнс } \\
\text { 3a 2015- } \\
2018 \text { pp. }\end{array}$ \\
\hline \multirow{8}{*}{$\begin{array}{l}\text { Красень } \\
\text { Полісся }\end{array}$} & $\begin{array}{l}\text { Без внесення } \\
\text { абсорбенту* }\end{array}$ & 120 & 87 & 104 & 120 & 108 \\
\hline & Таблетки & 132 & 106 & 120 & 132 & 123 \\
\hline & Гель & 180 & 167 & 174 & 180 & 175 \\
\hline & Гранули & 189 & 159 & 163 & 185 & 174 \\
\hline & Бетоніт & 175 & 101 & 140 & 169 & 146 \\
\hline & Калій & 178 & 143 & 146 & 178 & 161 \\
\hline & $\begin{array}{l}\text { Середні } \\
\text { гранули }\end{array}$ & 112 & 87 & 99 & 112 & 103 \\
\hline & Дрібні гранули & 101 & 176 & 139 & 101 & 129 \\
\hline \multirow{8}{*}{ Малахіт } & $\begin{array}{l}\text { Без внесення } \\
\text { абсорбенту }\end{array}$ & 125 & 147 & 136 & 125 & 133 \\
\hline & Таблетки & 158 & 122 & 160 & 158 & 150 \\
\hline & Гель & 192 & 153 & 173 & 192 & 178 \\
\hline & Гранули & 189 & 140 & 165 & 189 & 171 \\
\hline & Бетоніт & 130 & 128 & 129 & 130 & 129 \\
\hline & Калій & 152 & 136 & 154 & 157 & 150 \\
\hline & $\begin{array}{l}\text { Середні } \\
\text { гранули }\end{array}$ & 121 & 123 & 121 & 112 & 119 \\
\hline & Дрібні гранули & 130 & 117 & 148 & 150 & 136 \\
\hline $\mathrm{HIP}_{05}$ & $\begin{array}{l}\text { Фактор A } \\
\text { Фактор B } \\
\text { Взаємодія } A B\end{array}$ & $\begin{array}{l}12 \\
17 \\
63 \\
\end{array}$ & $\begin{array}{l}15 \\
20 \\
54\end{array}$ & $\begin{array}{l}10 \\
23 \\
65 \\
\end{array}$ & $\begin{array}{l}11 \\
25 \\
60\end{array}$ & \\
\hline
\end{tabular}

* - контроль, **-дані отримано Р.І. Прудким, О.І. Улянич

Встановлено, що урожайність шпинату городнього змінювалася відповідно до впливу погодних умов у роки досліджень і застосованої форми абсорбенту. Одержані результати показали, що внесені форми препарату мали неоднаковий вплив на врожайність шпинату городнього (табл. 3).

Суттєве збільшення величини врожаю шпинату городнього одержано за внесення абсорбенту у формі гелю, де урожайність сорту Красень Полісся становила 25,6 т/га, сорту Малахіт - 27,3 т/га, що додатково до контролю 10-11,7 т/га. Внесення гранул сприяло підвищенню 674 
урожайності до 21,8-24,4 т/га та переважало контроль на 6,2-8,8 т/га. Внесення гранул із калієм викликало зниження врожайності до 22,1-23,2 т/га, але вона переважала контроль на 6,5-7,6 т/га відповідно до сорту.

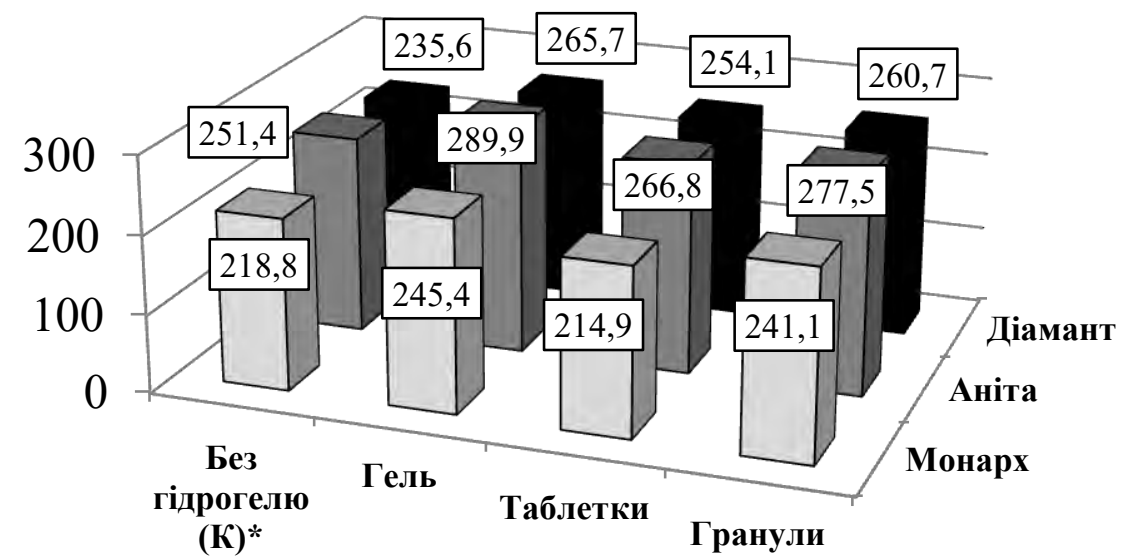

\section{Рис. 5. Маса рослини селери черешкової залежно від сорту та форми абсорбенту, г (середнс за 2015-2017 рр.)}

Дані отримані І.А. Діденком, О.І. Улянич

Позитивний результат отримано за застосування середніх і дрібних гранул для сортів Малахіт і Красень Полісся, в цьому випадку урожай збільшувався на 2,6-9,7 т/га. Внесення у грунт гранул із бетонітом дало змогу додатково отримати 2,5-3,6 т/га.

Результати дисперсійного аналізу отриманих даних показали, що на величину урожайності шпинату найбільший вплив мав фактор В або абсорбент та взаємодія факторів (рис. 6).

Фактор В або абсорбент впливав на цей процес на 33\%. Більшу силу впливу мала взаємодія факторів А і В - 54\%. Дія фактора А становила 13\%.

Облік товарної урожайності селери черешкової залежно від форми абсорбенту показав, що більша урожайність спостерігалась в усіх сортах за застосування гелю. Так, у сорту Монарх урожайність була на рівні 36,8 т/га, що на 4,1 т/га вище ніж у контролі, в сорту Аніта - 43,5 т/га (+ 10,8 т/га до контролю), в сорту Діамант - 39,8 т/га (+7,1 т/га до контролю). Нижчу врожайність спостерігали за застосування абсорбенту у формі таблеток, і сорти Діамант та Аніта мали показники 38,1 та 39,9 т/га, що становило приріст до контролю $+5,4$ та $+7,2$ т/га відповідно. Сорт Монарх мав показник нижчий за контроль на 0,5 т/га (32,2 т/га) (табл. 4).

Встановлено, що фактор А - рік - визначав величину товарної урожайності на $24 \%$, фактор В - сорт - на $25 \%$, фактор C - форма абсорбенту $-30 \%$ (рис. 7). 
Таблиця 3

Урожайність шпинату городнього

залежно від форми абсорбенту, т/га**

\begin{tabular}{|c|c|c|c|c|c|c|c|}
\hline $\begin{array}{c}\text { Сорт } \\
\text { фактор } \\
\text { A }\end{array}$ & $\begin{array}{l}\text { Препарат } \\
\text { фактор В }\end{array}$ & 2015 p. & 2016 p. & 2017 p. & 2018 p. & $\begin{array}{l}\text { Середнс } \\
\text { за 2015- } \\
2018 \text { pp. }\end{array}$ & $\begin{array}{c} \pm д о \\
\text { конт- } \\
\text { ролю }\end{array}$ \\
\hline \multirow{8}{*}{$\begin{array}{l}\text { Красень } \\
\text { Полісся }\end{array}$} & $\begin{array}{l}\text { Без внесення } \\
\text { абсорбенту* }\end{array}$ & 17,1 & 12,9 & 15,4 & 16,8 & 15,6 & 0 \\
\hline & Таблетки & 19,0 & 15,8 & 17,7 & 19,6 & 18,0 & $+2,4$ \\
\hline & Гель & 26,0 & 24,9 & 25,8 & 25,7 & 25,6 & $+10,0$ \\
\hline & Гранули & 25,1 & 16,2 & 21,0 & 24,9 & 21,8 & $+6,2$ \\
\hline & Бетоніт & 18,5 & 15,8 & 19,6 & 18,5 & 18,1 & $+2,5$ \\
\hline & Калій & 26,4 & 15,0 & 20,7 & 26,4 & 22,1 & $+6,5$ \\
\hline & $\begin{array}{l}\text { Середні } \\
\text { гранули }\end{array}$ & 14,8 & 25,9 & 20,4 & 15,1 & 19,0 & $+3,4$ \\
\hline & Дрібні гранули & 27,6 & 20,8 & 24,4 & 28,1 & 25,3 & $+9,7$ \\
\hline \multirow{8}{*}{ Малахіт } & $\begin{array}{l}\text { Без внесення } \\
\text { абсорбенту }\end{array}$ & 18,5 & 21,2 & 19,1 & 18,5 & 19,3 & $+3,7$ \\
\hline & Таблетки & 20,5 & 18,0 & 19,3 & 20,5 & 19,6 & $+4,0$ \\
\hline & Гель & 28,5 & 21,9 & 30,2 & 28,5 & 27,3 & $+11,7$ \\
\hline & Гранули & 22,4 & 23,9 & 24,7 & 26,4 & 24,4 & $+8,8$ \\
\hline & Бетоніт & 19,3 & 18,9 & 19,1 & 19,3 & 19,2 & $+3,6$ \\
\hline & Калій & 22,6 & 21,7 & 24,7 & 23,6 & 23,2 & $+7,6$ \\
\hline & $\begin{array}{l}\text { Середні } \\
\text { гранули }\end{array}$ & 17,9 & 18,7 & 18,3 & 17,9 & 18,2 & $+2,6$ \\
\hline & Дрібні гранули & 16,3 & 16,4 & 21,4 & 22,3 & 19,1 & $+3,5$ \\
\hline$H I P_{05}$ & $\begin{array}{l}\text { Фактор } A \\
\text { Фактор } B \\
\text { Взаємодія } A B\end{array}$ & $\begin{array}{l}0,3 \\
0,7 \\
0,9\end{array}$ & $\begin{array}{l}0,4 \\
0,9 \\
1,4\end{array}$ & $\begin{array}{l}0,3 \\
0,8 \\
1,3\end{array}$ & $\begin{array}{l}0,2 \\
0,7 \\
1,6\end{array}$ & & \\
\hline
\end{tabular}

*-контроль, **-дані отримано Р.І. Прудким, О.І. Улянич

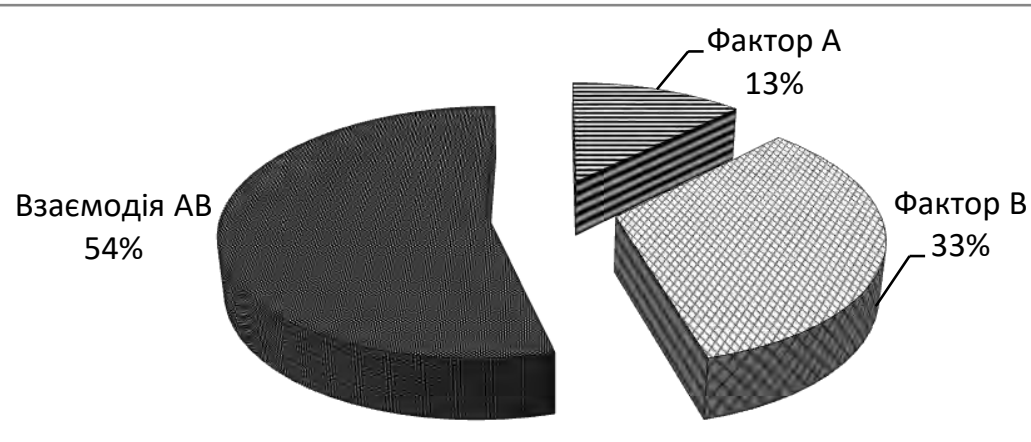

Рис. 6. Вплив факторів на урожайність шпинату городнього залежно від абсорбенту (середнє за 2015-2018 рр.), т/га

Дані отримано Р.І. Прудким, О.І. Улянич 
Таблиця 4

Товарна врожайність селери черешкової залежно від сорту

та форми абсорбенту, т/га (середне за 2015-2017 рр.)**

\begin{tabular}{|c|c|c|c|c|c|c|}
\hline \multirow[b]{2}{*}{$\begin{array}{c}\text { Сорт } \\
(\text { фактор A) }\end{array}$} & \multirow[b]{2}{*}{$\begin{array}{c}\text { Форма } \\
\text { абсорбенту } \\
\text { (фактор В) }\end{array}$} & \multicolumn{4}{|c|}{ Урожайність продукції, т/га } & \multirow[b]{2}{*}{$\begin{array}{c} \pm д о \\
\text { контролю }\end{array}$} \\
\hline & & 2015 p. & 2016 p. & 2017 p. & $\begin{array}{l}\text { Середнс } \\
\text { 3a 2015- } \\
2017 \text { pp. }\end{array}$ & \\
\hline \multirow{4}{*}{ Монарх } & Без абсорбенту * & 27,4 & 36,6 & 34,2 & 32,7 & 0 \\
\hline & Гель & 32,6 & 37,2 & 40,5 & 36,8 & $+4,1$ \\
\hline & Таблетки & 30,5 & 31,6 & 34,4 & 32,2 & $-0,5$ \\
\hline & Гранули & 30,9 & 38,6 & 38,8 & 36,1 & $+3,4$ \\
\hline \multirow{4}{*}{ Аніта } & Без абсорбенту & 32,2 & 41,9 & 38,9 & 37,7 & $+5,0$ \\
\hline & Гель & 39,7 & 47,3 & 43,4 & 43,5 & $+10,8$ \\
\hline & Таблетки & 38,3 & 39,4 & 42,1 & 39,9 & $+7,2$ \\
\hline & Гранули & 36,8 & 45,5 & 42,5 & 41,6 & $+8,9$ \\
\hline \multirow{4}{*}{ Діамант } & Без гідрогелю & 28,6 & 39,4 & 37,6 & 35,2 & $+2,5$ \\
\hline & Гель & 28,7 & 46,8 & 43,9 & 39,8 & $+7,1$ \\
\hline & Таблетки & 34,6 & 41,3 & 38,3 & 38,1 & $+5,4$ \\
\hline & Гранули & 36,2 & 39,8 & 41,2 & 39,1 & $+6,4$ \\
\hline$H I P_{05}$ & $\begin{array}{l}\text { фактор } A \\
\text { фактор } B \\
\text { взаємодія } A B\end{array}$ & $\begin{array}{l}1,7 \\
1,9 \\
3,3\end{array}$ & $\begin{array}{l}1,4 \\
1,6 \\
2,7\end{array}$ & $\begin{array}{l}1,9 \\
2,2 \\
3,8\end{array}$ & - & \\
\hline
\end{tabular}

* контроль; ** дані отримані І.А. Діденком, О.І. Улянич

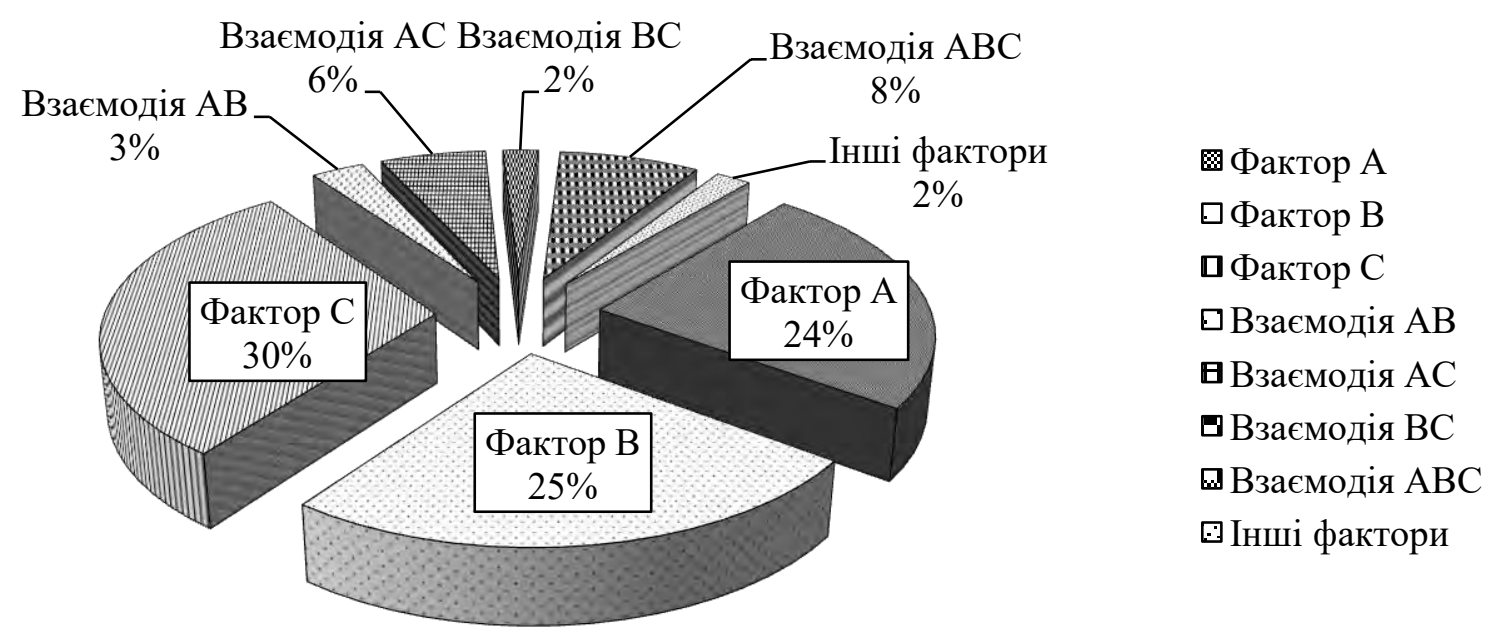

\begin{tabular}{|ll|}
\hline \multicolumn{2}{|c|}{ Фактори: } \\
$\mathrm{A}-\quad$ рік \\
$\mathrm{B}-$ & сорт \\
$\mathrm{C}-$ & форма абсорбенту \\
\hline
\end{tabular}

Рис. 7. Сила впливу факторів на товарну врожайність селери черешкової (середнє за 2015-2017 рр.) 
Доведено, що є сильний позитивний кореляційний зв'язок між масою рослини i кількістю листків $(\mathrm{r}=0,90)$, масою рослини $\mathrm{i}$ довжиною $\mathrm{i}$ діаметром черешка $(\mathrm{r}=0,79)$, врожайністю і масою однієї рослини або масою зібраної зелені з однієї рослини та цибулини $(\mathrm{r}=0,85)$.

$\mathrm{y}$ процесі роботи також було визначено залежності урожайності селери та показників якості продукції у вигляді емпіричних ліній регресії (рис. 8).
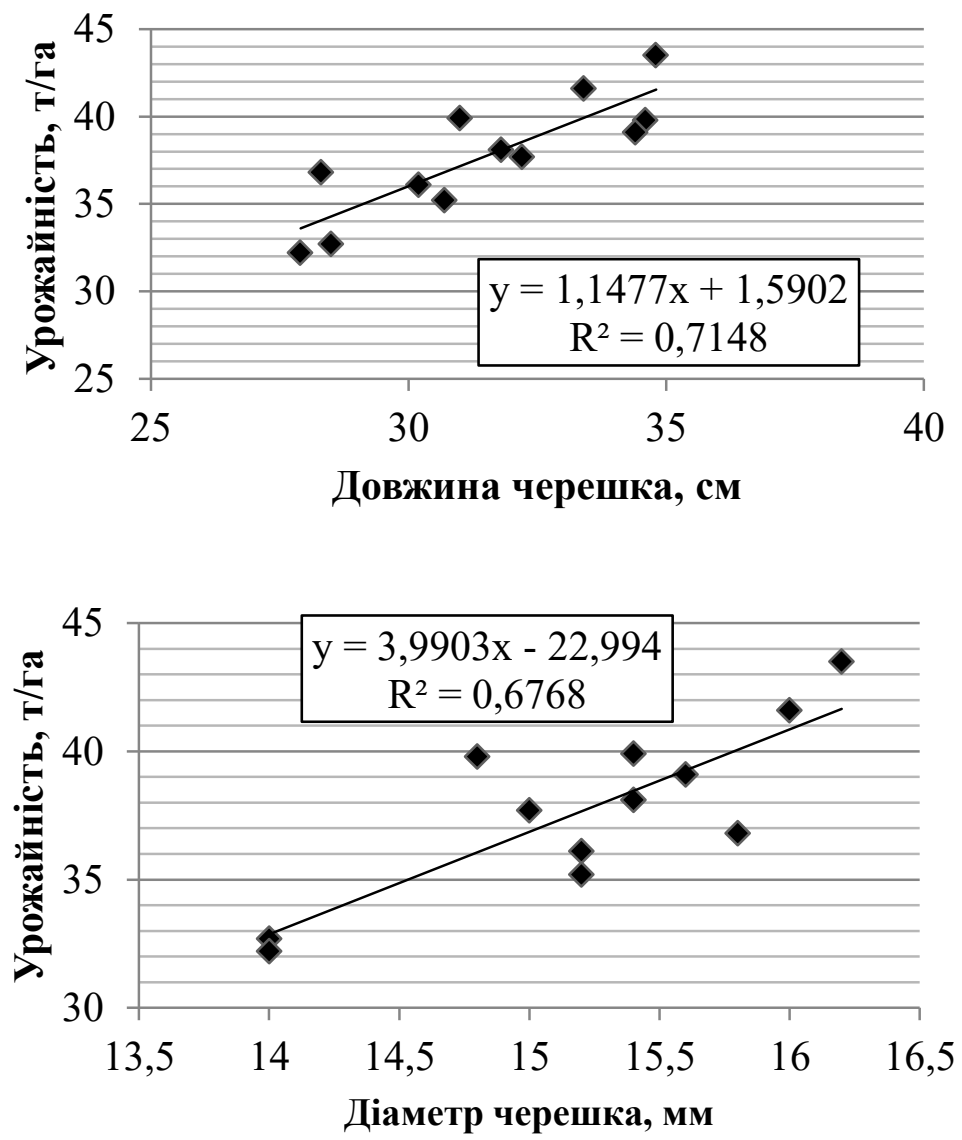

\section{Рис. 8. Залежність між урожайністю, довжиною та діаметром} черешка селери черешкової (середнс за 2015-2017 рр.)

Дані отримані І.А. Діденком, О.І. Улянич

Рівняннями регресії визначено, що з підвищенням маси надземної частини рослини на одиницю ваги врожайність буде підвищуватись (рис. 9).

Наведені математичні залежності вказують на існування лінійного зв'язку між урожайністю селери черешкової, довжиною, діаметром, масою надземної частини рослини та іншими показниками якості. Про високу щільність зв'язку між цими показниками свідчать також значення коефіцієнтів детермінації, які знаходяться на рівні $\mathrm{R}^{2}=0,6768-0,9173$. 


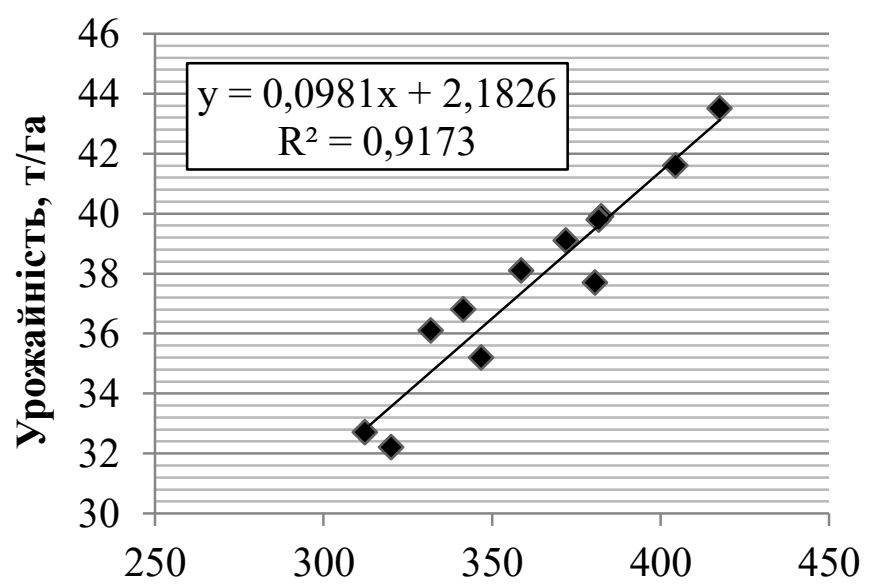

Маса надземної частини рослини, г

\section{Рис. 9. Залежність урожайністю та масою надземної частини рослини. (Середнс за 2015-2017 рр.)}

Дані отримані І.А. Діденком, О.І. Улянич

Математичними рівняннями доведено, що зі збільшенням довжини та діаметру черешка, відповідно, збільшується урожайність.

\section{3. Якість продукції овочевих рослин залежно від форми абсорбенту}

Як зазначають вчені-дослідники, шпинат та інші овочі мають багатий хімічний склад ${ }^{18,19,20 .}$

Визначення хімічного складу листків шпинату городнього показало, що форма абсорбенту не впливала негативно на показники. Порівняно 3 контролем, де рослини вирощували без застосування абсорбенту, у варіантах досліду збільшувалася масова частка сухої речовини, цукрів і вітаміну С. Так, шпинат городній сортів Красень Полісся і Малахіт мав вищий вміст сухої речовини в листках за застосування абсорбенту фірми Максимарин у формі гранул і гелю - 8,1-8,9\% (табл. 7).

Вміст сухої розчинної речовини в листках шпинату городнього сортів Красень Полісся і Малахіт був на рівні 5,0-6,3\% і був вищим за застосування абсорбенту у формі гранул і гелю - 5,6-6,3\%.

Масова частка цукрів залежно від сорту та форми препарату коливалася в межах 2,2-2,9\% і знаходилася майже на однаковому рівні. Вищим вмістом цукрів відрізнялися рослини, вирощені за застосування абсорбенту у формі гранул і гелю - 2,6-2,9\% та гранул ыз калієм фірми Еко - 2,7-2,8\%.

18 Швецов А.С., Пичкина В.П. Оценка образцов шпината по химическому составу. Tpyдbl no прикладной ботанике, генетике, селекции. 1981. Т. 40, Вып. 1. С. 56-61.

19 Шиврина А.Н. Биохимия шпината, щавеля, ревеня. Биохимия овощңных культур. Москва, 1961. C. 304-324.

${ }^{20}$ Aworh O.C., Hicks I.R., Minotti P.L., Loe C.G. Effect of plant ageand nitrogen fertilisation nitrite accumulation in frech Spinach. J. Amer. Soc. HortSci. 1980. 105. № 1. P. 18-20. 
Вміст вітаміну С знаходився в межах 47-64 мг/100 г залежно від форми внесеного препарату. За вмістом вітаміну С переважали рослини, вирощені за застосування гранул і гелю - 56-62\% та гранул з калієм фірми Еко - 58-64\% відповідно до сорту.

Таблиця 7

Хімічний склад шпинату городнього залежно від форми абсорбенту

\begin{tabular}{|c|c|c|c|c|c|c|}
\hline $\begin{array}{c}\text { Сорт } \\
\text { фактор A }\end{array}$ & $\begin{array}{l}\text { Препарат } \\
\text { фактор B }\end{array}$ & 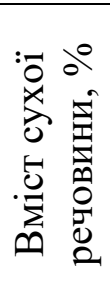 & 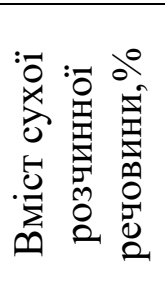 & 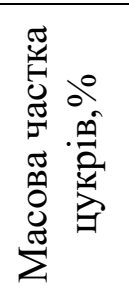 & 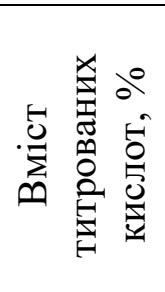 & 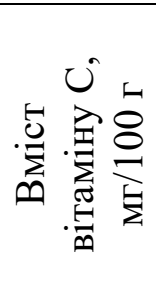 \\
\hline \multirow{8}{*}{$\begin{array}{l}\text { Красень } \\
\text { Полісся }\end{array}$} & $\begin{array}{l}\text { Без внесення } \\
\text { абсорбенту* }\end{array}$ & 6,2 & 5,1 & 2,2 & 0,16 & 47 \\
\hline & Таблетки & 7,4 & 5,5 & 2,4 & 0,17 & 51 \\
\hline & Гель & 8,7 & 5,8 & 2,6 & 0,20 & 56 \\
\hline & Гранули & 8,4 & 5,6 & 2,7 & 0,21 & 57 \\
\hline & Бетоніт & 6,3 & 5,1 & 2,6 & 0,22 & 54 \\
\hline & Калій & 7,7 & 5,4 & 2,7 & 0,20 & 58 \\
\hline & $\begin{array}{l}\text { Середні } \\
\text { гранули }\end{array}$ & 6,4 & 5,1 & 2,6 & 0,22 & 54 \\
\hline & Дрібні гранули & 6,5 & 5,4 & 2,7 & 0,20 & 58 \\
\hline \multirow{8}{*}{ Малахіт } & $\begin{array}{l}\text { Без внесення } \\
\text { абсорбенту }\end{array}$ & 6,4 & 5,0 & 2,3 & 0,19 & 51 \\
\hline & Таблетки & 7,7 & 5,7 & 2,5 & 0,20 & 55 \\
\hline & Гель & 8,9 & 6,3 & 2,7 & 0,17 & 59 \\
\hline & Гранули & 8,1 & 6,2 & 2,9 & 0,22 & 62 \\
\hline & Бетоніт & 7,1 & 5,1 & 2,5 & 0,30 & 62 \\
\hline & Калій & 8,0 & 5,4 & 2,8 & 0,21 & 64 \\
\hline & $\begin{array}{l}\text { Середні } \\
\text { гранули }\end{array}$ & 7,3 & 5,1 & 2,6 & 0,22 & 54 \\
\hline & Дрібні гранули & 7,0 & 5,0 & 2,7 & 0,20 & 58 \\
\hline
\end{tabular}

*контроль; **дані отримано Р.І. Прудким, О.І. Улянич

Дослідження вмісту радіонуклідів у грунті показали, що кількість Cs-137, K-40, Ra-226, Th-232 знаходилася в межах норми. Але за вмістом радіонуклідів у продукції овочевих рослин виявлено певну закономірність: із застосуванням гелю овочева продукція мала дещо вищу концентрацію Cs-137 та Sr-90 порівняно 3 контролем, проте гранично допустимого рівня не перевищено.

\section{ВИСНОВКИ}

Встановлено, що внесення абсорбентів у грунт у формі гелю і гранул сприяло ранішому проростанню рослин i надходженню врожаю 
шпинату городнього на 7-9 діб, селери черешкової - на 4-6, часнику посівного - 4-6 діб. Строк збирання врожаю в інших варіантах досліду спостерігався пізніше на 1-2 доби.

Вирощування шпинату на фоні застосування різних форм абсорбенту сприяло збільшенню кількості листків і за внесення абсорбенту у вигляді гелю в сорту Красень Полісся сприяло збільшенню кількості листків до 22 шт./росл., у сорту Малахіт - до 23 шт./росл., що переважало контроль на 6-7 шт./росл. Внесення гранул викликало дещо нижчий ефект, але перевага до контролю була досить високою і становила 5-6 шт./росл.

Доведено, що застосування абсорбентів у вирощуванні селери черешкової з використанням різних форм сприяє одержанню високоякісних черешків та підвищенню врожайності селери. Довжина черешка селери залежно від сорту та форми абсорбенту змінювалася в межах 27,9-34,8 см і більшою була за застосування гранул - 30,2-34,4 см та гелю - 34,6-34,8 cм, а площа листків у сорту Монарх за внесення таблеток $-16,9$ тис. ${ }^{2} /$ га.

Застосування гелю позитивно впливало на кількісні показники і рівень урожайності селери черешкової. Маса вегетативної частини рослини була більшою за використання гелю в сорту Аніта - 417,6 г. Маса черешків з однієї рослини також більша за застосування гелю і в сорту Монарх становила 245,4 г, у сорту Аніта - 289,9 г, у сорту Діамант 265,7 г. Вищою урожайністю позначився сорт Аніта за застосування гелю - 43,5 т/га, нижчою - сорт Діамант (39,8 т/га) та Монарх (36,8 т/га). Рівняннями регресії підтверджено, що зі збільшенням довжини та діаметру черешка, маси надземної частини рослини, відповідно, збільшується і врожайність (коефіцієнт детермінації $\mathrm{R}^{2}=0,6768-0,9173$ ).

Розроблено науково-методичні підходи та доведено позитивний вплив застосування абсорбенту на ріст і розвиток досліджуваних овочевих рослин. $\mathrm{HIP}_{05}$ в кількісному виразі за факторами врожайності становила $0,02-0,03$, що вказує на достовірні значення між їх повтореннями i варіантами.

Встановлено, що внесення абсорбенту не впливає негативно на показники грунту та якість продукції, оскільки вміст радіонуклідів і інших шкідливих речовин у грунті та продукції селери черешкової не підвищується і не перевищує гранично допустиму концентрацію.

Три фактори (рік вирощування - 24\%, генетичний потенціал сорту $25 \%$ i абсорбент - 30\%) сумарно формують урожайність шпинату городнього, селери черешкової та часнику посівного в умовах Правобережного Лісостепу України.

\section{АНОТАЦІЯ}

Застосування для вирощування шпинату городнього, селери черешкової, часнику посівного абсорбентів сприяло швидшому 
проростанню насіння, посилювало ріст і розвиток рослин та зумовлювало збільшення виходу товарної врожайності продукції на 2,0-6,1 т/га та підвищенню іï якості.

Встановлено, що $є$ сильний позитивний кореляційний зв'язок між масою рослини і кількістю листків $(\mathrm{r}=0,90)$, масою рослини і діаметром розетки $(\mathrm{r}=0,79)$, врожайністю товарної зелені шпинату городнього $\mathrm{i}$ масою однієї рослини або масою зібраної зелені з однієї рослини $(\mathrm{r}=0,85)$.

Застосування гелю позитивно впливало на кількісні показники і рівень урожайності селери черешкової, маса вегетативної частини рослини ставала більшою за використання гелю в сорту Аніта - 417,6 г, маса черешків з однієї рослини за застосування гелю в сорту Монарх становила 245,4 г, Аніта - 289,9 г, Діамант - 265,7 г. Вищою урожайністю позначився сорт Аніта за застосування гелю - 43,5 т/га.

Рівняннями регресії підтверджено, що зі збільшенням довжини та діаметру черешка, маси надземної частини рослини, відповідно, збільшується і врожайність (коефіцієнт детермінації $\mathrm{R}^{2}=0,6768-0,9173$ ).

Розроблено науково-методичні підходи та доведено позитивний вплив застосування абсорбенту на ріст і розвиток досліджуваних овочевих рослин. $\mathrm{HIP}_{05}$ в кількісному виразі за факторами врожайності становила $0,02-0,03$, що вказує на достовірні значення між їх повтореннями $\mathrm{i}$ варіантами.

Встановлено, що внесення абсорбенту не впливає негативно на показники грунту та якість продукції, оскільки вміст радіонуклідів і інших шкідливих речовин у грунті та продукції овочів не підвищується і не перевищує гранично допустиму концентрацію.

\section{ЛІТЕРАТУРА}

1. Ulianych O.I., Schetyna S.V., Slobodianyk G.Ya., Ternavskyi A.G., Kuhniuk O.V., Didenko I.A. Ecological Status of Soils and Vegetable Products in Cherkasy Region. Ukrainian Journal of Ecology. 2018. 8(3). 10-19. DOI: 10.15421/2018_317.

2. Polischuk V.V., Polischuk T.V., Kezkalo V.V., Vorobiova N.V. Effect of application of modified nourishing environment on the reproduction and yielding capacity of root celery. Ukrainian Journal of Ecology. 2018. 8(2). 113-119. DOI: 10.15421/2018 317.

3. AGPRO NZ Limited WATER RETENTION CRYSTALS WaterAbsorbentPolymer. URL: http://www.agpro.co.nz/label/AGPRO\%20 Water\%20Retention\%20Crystals.pdf

4. Aworh O.C., Hicks I.R., Minotti P.L., Loe C.G. Effect of plant ageand nitrogen fertilisation nitrite accumulation in frech Spinach. J. Amer. Soc. HortSci. 1980. 105. № 1. p. 18-20. 
5. Kosterna, E., Zaniewicz-Bajkowska, A. (2012). The effect of Agro Hydro Gel and irrigationin celery acyieldand quality. Folia Horticulturae. Annalis, 2012. $297 \mathrm{p}$.

6. Osokina N., Kostetska K., Kuhnyuk O., Shevchuk K. Quality management of vegetables with the application of nano preparations. Збірник наукових праць Уманського національного університету садівництва. Ч. I. Сільськогосподарські науки. Вип. 96. 2020. С. 179-193. DOI 10.31395/2415-8240-2020-96-1-178-193.

7. Ulianych O., Kostetska K., Vorobiova N., Shchetyna S., Slobodyanyk G. and Shevchuk K. Growth and yield of spinach depending on absorbents' action. Agronomy Research 18(X), xxx-ccc, 2020. https://doi.org/10.15159/ AR.20.012.

8. Воробйова Н.В., Кухнюк О.В., Прудкий Р.І. Нанотехнології в овочівництві України. VI (21), Issue 179, 2018. Sept. SCIENCE AND EDUCATION A NEW DIMENSION. Natural and Technical Sciences. C. 13-15. https://doi.org/10.31174/SEND-NT2018-179VI21-03.

9. Гидрогель в растениеводстве. URL: http://www.avroragro.ru.

10. Гідрогель AQUASORB. URL: http://www.gidrogel.org.

11. Діденко I.A. Оптимізація технології вирощування селери черешкової у Правобережному Лісостепу України : автореф. дис. ... канд. с.-г. наук : 06.01.06 «Овочівництво». Умань, 2018. 24 с.

12. Диденко И.А., Яценко В.В. Выращивание сельдерея черешкового при помощи различных форм гидрогеля в условиях Правобережной Лесостепи Украины. Инновационные подходы и перспективные идеи молодых ученых в аграрной науке : Сборник материалов Международной научно-практической конференции молодых учёных, 17 ноября 2017 г., п. Кайнар. Innovative approaches and perspective ideas of young scientists in agrarian sciences: The proceed. of intern. sc. pract. conf. young scient. November 17, 2017, KainarTown. Алматы : Таугуль-Принт, 2017. C. $552-555$.

13. Курченко А.А., Коваль В.В. Урожайність сортів шпинату городнього залежно від водоутримуючих речовин. Технологічні аспекти вирощування часнику, інших иибулевих $i$ с.-г. рослин : Всеукраїнська науково-практична конференція, 21-22.09.2017. Умань. 2017. С. 40-45.

14. Паламарчук I.I. Ефективність застосування водоутримуючих гранул Аквод при вирощуванні кабачка за мульчування грунту в Правобережному Лісостепу України. Збірник наукових праџь НУБІП. 2014. Вип. 40. С. 74-81.

15. Прудкий P.I. Технологічні особливості формування урожайності шпинату городнього за органічного виробництва у Правобережному Лісостепу України : автореф. дис. ... канд. с.-г. наук : 06.01 .06 «Овочівництво». Умань, 2019. 25 с. 
16. Улянич О.І., Вдовенко С.А., Ковтунюк 3.І., Кецкало В.В. та ін. Біологічні особливості $i$ вирощування малопоширених овочів. Навчальний посібник. Умань : Візаві, 2018. 280 с.

17. Ульянич Е.И., Диденко И.А., Яценко В.В. Выращивание сельдерея черешкового при помощи различных форм гидрогеля в условиях Правобережной Лесостепи Украины. Инновационные подходы $u$ перспективные идеи молодых ученых в аграрной науке : Сборник матлов Междунар. науч.-практ. конф. мол. уч., 17 ноября 2017 г., п. Кайнар. Innovative approaches and perspective ideas of young scientists in agrarian sciences: The proceed. of intern. sc. pract. conf. young scient. (November 17, 2017, KainarTown). Алматы : Таугуль-Принт, 2017. С. 552-555.

18. Ульянич Е.И, Алексейчук О.М., Прудкий Р.И., Диденко И.А. Применение биопрепаратов для получения экологически безопасной продукции шпината огородного и сельдерея черешкового. Hаучные статьи Государственного аграрного университета Молдовы. Вып. 42. 2015. C. 225-227.

19. Швецов А.С., Пичкина В.П. Оценка образцов шпината по химическому составу. Tруды по прикладной ботанике, генетике, селекиии. 1981. Т. 40, Вып. 1. С. 56-61.

20. Шиврина А.Н. Биохимия шпината, щавеля, ревеня. Биохимия овощңных культур. Москва, 1961. С. 304-324.

\section{Information about authors: Ulianych O. I.,}

Doctor of Agricultural Sciences, Professor, Head of the Department of Vegetable Growing of the Faculty of Horticulture, Ecology and Plants Protection

Uman National University of Horticulture 1, Institutskaya str., Uman, Cherkasy region, 20300, Ukraine

Shevchuk K. M., Candidate of Agricultural Sciences, Nunhems Ukraine LLC 19, Druzhby Narodiv blvd, Kyiv, 01042, Ukraine 